\title{
Crystal Structure of Tetrakis(2,2'-bithiophene-5-yl)silane
}

\author{
ELENA BIANCA (GEORGESCU) STOICA ${ }^{1,2,3}$, CATHERINE BRANGER ${ }^{1}$, TANTA VERONA IORDACHE ${ }^{2}$, ANDREI SARBU ${ }^{2}$, \\ HORIA IOVU3 ${ }^{3}$ OLEG B. VITRIK ${ }^{4,5}$, ANTON V. DYSHLYUK ${ }^{4,5}$, HUGUES BRISSET ${ }^{2 *}$ \\ ${ }^{1}$ Laboratoire MAPIEM, Universite de Toulon, CS 60584, Toulon cedex 9, 83041, France \\ ${ }^{2}$ National Research-Development Institute for Chemistry and Petrochemistry, Polymer Department, Advanced Polymer Materials \\ and Polymer Recycling Team, 202 Splaiul Independentei, 060021, Bucharest, Romania \\ ${ }^{3}$ University Politehnica of Bucharest, Faculty of Applied Chemistry and Materials Science, Advanced Polymer Materials Department, \\ 1-7 Gh. Polizu Str., Bucharest, 011061, Romania \\ ${ }^{4}$ Institute of Automation and Control Processes, Far Eastern Branch of Russian Academy of Sciences, Vladivostok, Russian \\ Federation \\ ${ }^{5}$ Far Eastern Federal University, Vladivostok, Russia
}

The crystal structure of tetrakis(2,2'-bithiophene-5-yl) silane, $\mathrm{C}_{16} \mathrm{H}_{10} \mathrm{S4Si} \mathrm{i}_{0.5^{\prime}}$ has been determined at $293 \mathrm{~K}$ in the Monoclinic (I2) symmetry. The Si atom has quasi-perfect tetrahedral geometryand bithiophene unitare quasi-planar. Comparison of Si-C bond lengths with literature data indicates an electron donating effect of the terminal thienyl ring on the first $\mathrm{C}$ linked to the Si central atom. The study of $\mathrm{C}-\mathrm{C}$ bond lengths reveals a much more aromatic character for the four thienyl rings directly linked to the Si atom. The molecular packing arrangement shows that each molecule presents eight intermolecular contacts.

Keywords: crystal structure; tetrahedral; bithiophene; silane

In recent years, tetrahedral thiophene derivatives have been the focus of attention in organic electronics, particularly to solve low solubility problems of $\pi$-conjugated systems [1]. Several silanes tetrasubstituted by oligothiophenes having a supposed tetrahedral symmetry have been described as 3D electro-active $\pi$-conjugated material [2] as donor materials for organic solar cells $[3,4]$. In another field, conducting polymers have been largely studied to develop chemical sensors [5]. Thereby, they have been investigated to prepare molecularly imprinted polymers [6-8] acting both as recognition and transducing phase for electrochemical detection of molecular targets [9]. In order to improve and stabilize the imprinting effect, one of the challenges is to prepare imprinted conducting polymers with a tetrahedral cross-linker $[10,11]$. In our ongoing research on surface plasmon resonance sensors [12], we develop an imprinted conducting polymer with tetrakis(2,2'-bithiophene) silane (fig. 1) as cross-linker to maintain the 3D network of the sensing phase. In order to confirm its tetrahedral geometry we have resumed its synthesis [13] and determined its crystal structure.

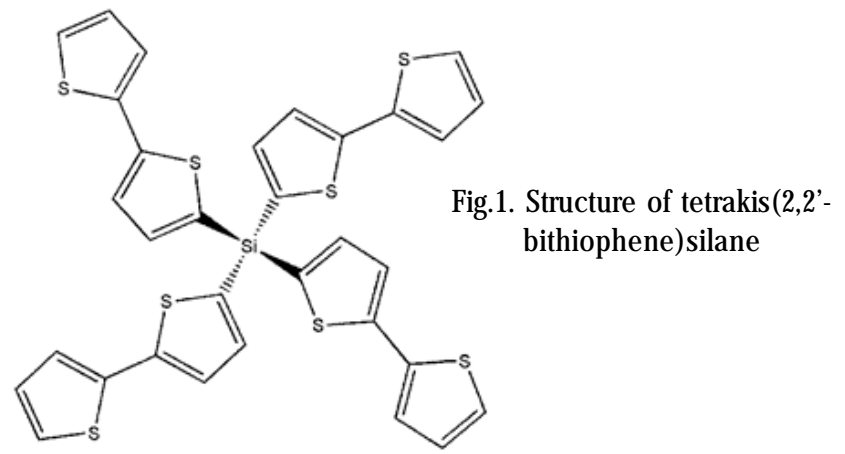

Table 1

CRYSTAL DATA, DATA COLLECTION AND STRUCTURE REFINEMENT. CAMBRIDGE CRYSTALLOGRAPHIC DATA CENTRE NUMBER: CCDC 1846056. COMPUTER PROGRAMS: CRYSALIS PRO 1.171.38.43 (RIGAKU OD, 2015), SHELXS (SHELDRICK, 2008), SHELXL (SHELDRICK, 2015), OLEX2 (DOLOMANOV ET AL., 2009)

\begin{tabular}{||c|c||}
\hline \multicolumn{2}{|c||}{ Crystal data } \\
\hline \hline Chemical formula & C16H10S4Si0.5 \\
\hline \hline Mr & 344.52 \\
\hline \hline Crystal system, space group & Monoclinic, I2 \\
\hline \hline Temperature (K) & 293 \\
\hline \hline $\mathrm{a}, \mathrm{b}, \mathrm{c}(\AA)$ & $13.6388(6), 8.1961(3), 14.6700(6)$ \\
\hline \hline$\beta\left(^{\circ}\right)$ & $97.594(4)$ \\
\hline \hline $\mathrm{V}(\AA 3)$ & $1625.49(11)$ \\
\hline \hline $\mathrm{Z}$ & 4 \\
\hline \hline Radiation type & $\mathrm{MoK} \alpha$ \\
\hline$\mu(m m-1)$ & 0.61 \\
\hline Crystal size $(\mathrm{mm})$ & $0.24 \times 0.16 \times 0.1$ \\
\hline
\end{tabular}

* email: brisset@univ-tln.fr 


\begin{tabular}{|c|c|}
\hline \multicolumn{2}{|r|}{ Data collection } \\
\hline Diffractometer & SuperNova, Dual, Cu at zero, AtlasS2 \\
\hline Absorption correction & $\begin{array}{c}\text { Multi-scan } \\
\text { CrysAlis PRO 1.171.38.43 (Rigaku Oxford Diffraction, 2015) Empirical } \\
\text { absorption correction using spherical harmonics, implemented in SCALE3 } \\
\text { ABSPACK scaling algorithm. }\end{array}$ \\
\hline Tmin, Tmax & $0.866,1.000$ \\
\hline $\begin{array}{l}\text { No. of measured, independent and } \\
\text { observed }[I>2 \sigma(I)] \text { reflections }\end{array}$ & $5237,3166,2878$ \\
\hline Rint & 0.017 \\
\hline$(\sin \theta / \lambda) \max (\AA-1)$ & 0.657 \\
\hline \multicolumn{2}{|r|}{ S Structure Refinement } \\
\hline $\mathrm{R}[\mathrm{F} 2>2 \sigma(\mathrm{F} 2)], \mathrm{wR}(\mathrm{F} 2), \mathrm{S}$ & $0.048,0.144,1.09$ \\
\hline No. of reflections & 3166 \\
\hline No. of parameters & 186 \\
\hline No. of restraints & 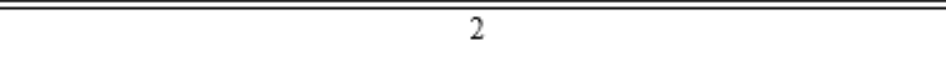 \\
\hline 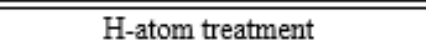 & H-atom parameters constrained \\
\hline$\Delta \rho \max , \Delta \rho \min (\mathrm{e} \AA-3)$ & $0.47,-0.33$ \\
\hline Absolute structure & $\begin{array}{c}\text { Flack x determined using } 1186 \text { quotients [(I+)-(I-)]/[(I+)+(I-)] (Parsons, Flack } \\
\text { and Wagner, Acta Cryst. B69 (2013) 249-259). }\end{array}$ \\
\hline Absolute structure parameter & $0.08(4)$ \\
\hline
\end{tabular}

\section{Experımentaı part}

Tetrakis(2,2'-bithiophene-5-yl) silane was synthesized in one-step reaction from commercial bithiophene. A solution of $2.0 \mathrm{~g}(0.012 \mathrm{~mol})$ of 2,2'-bithiophene in $35 \mathrm{~mL}$ of anhydrous diethylether was placed under argon atmosphere and cooled at $-40^{\circ} \mathrm{C}$ before addition of $6.0 \mathrm{~mL}$ $(0.015 \mathrm{~mol}) \mathrm{n}$-BuLi (2.5 M in hexane). After one hour, 1.8 $\mathrm{mL}(0.012 \mathrm{~mol})$ of tetramethoxysilane was added and the temperature increased to $-20^{\circ} \mathrm{C}$. After $2 \mathrm{~h}$ at $-20^{\circ} \mathrm{C}$, the mixture was diluted with dichloromethane and washed with water and introduced in a funnel for extraction. The aqueous phase was removed. The organic phase was dried with magnesium sulphate and filtrated. Finally, the solvents were evaporated using a rotary evaporator. Purification was performed on silica gel column with a mixture of cyclohexane/ethyl acetate (80/20) as eluent. The target compound was finally crystallized to give colourless singlecrystal for X-ray diffraction analysis (details are summarized in table 1 ) and ${ }^{1} \mathrm{H}$ NMR. The compound analysis was carried out using a BrukerAvance 300 NMR and MestReNova software. MP: $154-155^{\circ} \mathrm{C}$. ${ }^{1} \mathrm{H}$ NMR (400 $\left.\mathrm{MHz}, \mathrm{CDCl}_{3}\right) \delta(\mathrm{ppm}): \delta 7.49(\mathrm{~d}, 3 \mathrm{~J}=3.6 \mathrm{~Hz}, 4 \mathrm{H}), 7.37(\mathrm{~d}$, $3]=3.6 \mathrm{~Hz}, 4 \mathrm{H}), 7.28(\mathrm{dd}, 3]=3.6 \mathrm{~Hz}, 5=1.2 \mathrm{~Hz}, 4 \mathrm{H}), 7.26(\mathrm{dd}$, $3 \mathrm{~J}=3.6 \mathrm{~Hz}, 5 \mathrm{f}=1.2 \mathrm{~Hz}, 4 \mathrm{H}), 7.05(\mathrm{dd}, 3 \mathrm{~J}=3.6 \mathrm{~Hz}, 3 \mathrm{~J}=3.6 \mathrm{~Hz}$, 4H). ${ }^{13} \mathrm{C} \mathrm{NMR}\left(100 \mathrm{MHz}, \mathrm{CDCl}_{3}\right), \delta(\mathrm{ppm}): 124,124.5,125.5$, $128,132,137,139.5,145.5$.

\section{Result and discussions}

The compound presented in ORTEP drawing in figure 2 crystallizes in the monoclinic space group 12. The crystal structure of tetrakis (2,2'-bithiophene-5-yl) silane is obtained from two half molecules in the asymmetric unit with an angle of $110.32^{\circ}$ between C1-Si-C9 atoms. The coordination sphere around the Si atom is quasi-perfectly tetrahedral with angles from $108.71^{\circ}$ for $\mathrm{Cl}-\mathrm{Si}-\mathrm{Cl}$ angle to $110.33^{\circ}$ for $\mathrm{Cl}$-Si-C9. The Si-C bond lengths of $1.848 \AA$ (Si-C9) and $1.854 \AA$ ( $\mathrm{Si}-\mathrm{C} 1$ ) are a little shorter than those in tetrakis (2-

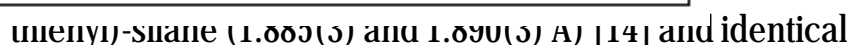
to bond length found for tetrakis (3,4-ethylenedioxy-2thienyl)-silane [1.848(2) $\AA$ ] [15] which indicate an electron donating effect of the thienyl ring on the first one linked to $\mathrm{Si}$ atom. The average C-S bonds [1.716 (5) $\AA$ ] of thienyl ring linked to $\mathrm{Si}$ atom are similar to those of tetrakis(2thienyl)-silane with $1.714 \AA$ [14] or thienyl rings in bithiophene [16] and in $\alpha$-terthienyl [17]. $C=C$ bond lengths in the thienyl ring linked to Si atom [C1-C2: 1.346(9) $\AA ; C 3$ C4: 1.370(9) $\AA$ and C9-C10: 1.369(7) $\AA$; C11-12: 1.38(8) $\AA]$ are similar to those of $\alpha$-terthienyl i.e. shorter than C2-C3: 1.40(1) $\AA$ and C10-C11: 1.41(1) A.

As far as the second thienyl ring of tetrakis(2,2'bithiophene-5-yl) silane is concerned, the average C-S bonds $[1.684(5) \AA]$ are shorter than for the thienl ring directly linked to Si. Furthermore, C5-C6 [1.483(8)] $\AA$ and C13-C14 [1.496(8) $\AA$ ] are longer than C6-C7 [1.45(1) $\AA$ ] and C14C15 [1.47(1) A], which indicates for these successive bonds a Csp2-Csp2 single bond distance [1.48 Å]. From these observations, the thienyl ring linked to $\mathrm{Si}$ atom seems to be more aromatic than the second thienyl ring. This is confirmed by the difference between average Csp2-Csp2 bond lengths of thienyl ring linked to Si atom (1.37 $\AA$ ) to the end thienyl (1.42 $\AA$ ). Angles of 11.50 and $14.72^{\circ}$ between thienyl rings are measured on asymmetric unit whereas the thienyl rings are coplanar in bithiophene or $\alpha$ terthienyl. So these twist angles could explain the different aromatic character of the two thienyl rings in tetrakis $\left(2,2^{\prime}\right.$ bithiophene-5-yl) silane.

In the asymmetric unit, for one bithiophene each thienyl ring has one contact with two other molecules (fig 2).

For the other bithiophene, only the end thienyl ring has two contacts with two other molecules. In fact, the $\mathrm{H}$ and $S$ atoms of end thienyl ring have intermolecular contacts with the $\mathrm{C}$ atom of the thienyl ring linked to $\mathrm{Si}$ atom of one molecule [C-H 2.871 $\AA$ ] and $\mathrm{H}$ atom of thienyl ring of other one molecule [S-H 2.888Å]. Finally, each molecule has 


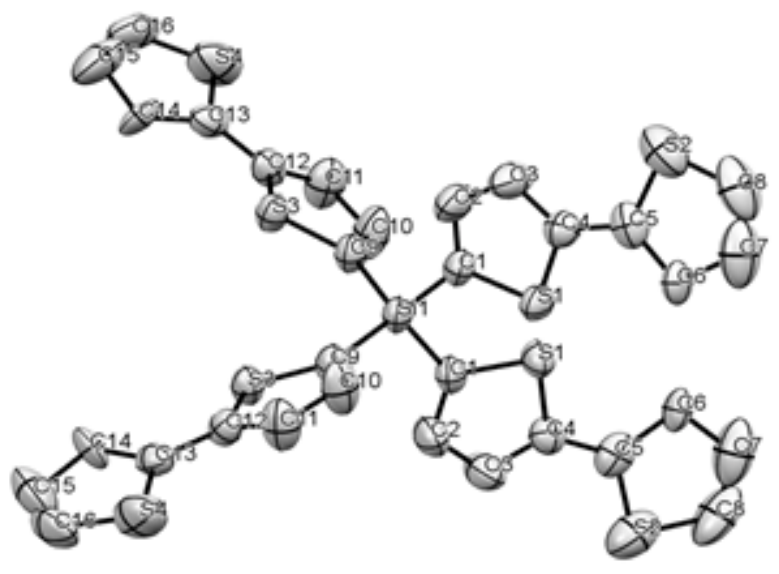

Fig. 2. The structure of tetrakis(2,2'-bithiophene-5-yl)silane showing $25 \%$ probability displacement ellipsoids and the atomic numbering scheme. $\mathrm{H}$ atoms have been omitted for clarity

eight intermolecular contacts with six other molecules because two $\mathrm{C}-\mathrm{H}$ intermolecular contacts are made between two molecules (fig 3).

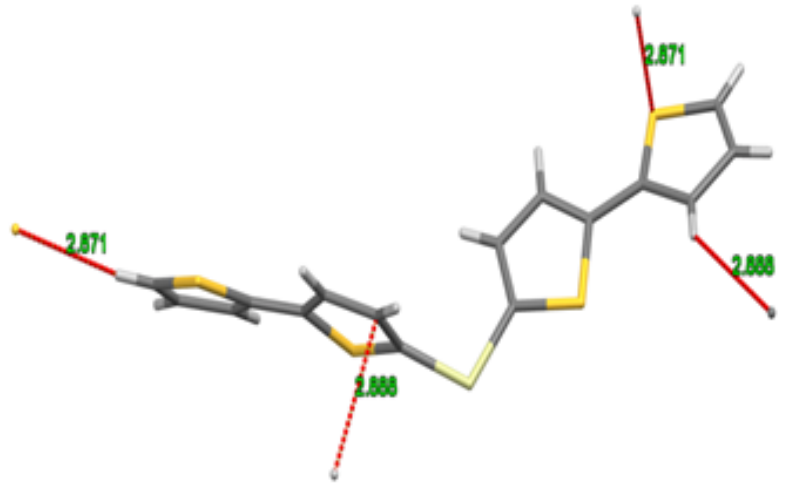

Fig. 3. Asymmetric unit of tetrakis(2,2'-bithiophene-5-yl)silane with intermolecular contacts

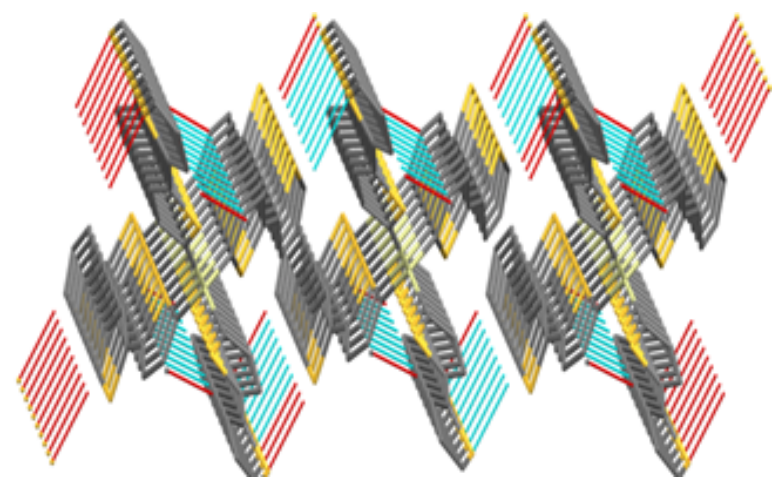

Fig. 4. Asymmetric unit of tetrakis(2,2'-bithiophene-5-yl)silane with short contacts

\section{Conclusions}

In conclusion, tetrakis(2,2'-bithiophene-5-yl) silane was synthesized to confirm its tetrahedral geometry. The compound gave colourless crystal in cyclohexane. Single- crystal X-ray diffraction has shown a monoclinic symmetry, eight intramolecular interaction between the bithiophenyl moieties and as expected a tetrahedral silicon. A significant difference of structure was observed between the two thienyl rings of the bithiophenyl substituents which were ascribed to partial loss of aromaticity of the ring farthest from the central Si.

Acknowledgements: The authors thank to the National Funding Organizations, ANR (France) and UEFISCDI (Romania) and the European Commission, which founded the supporting projectSNIFF ERANET-RUS 10/2016 and to the Core project PN.18.22.03.01.02.

\section{References}

1. MATSUMOTO, K., TANAKA, T., KUGO, S., INAGAKI, T., HIRAO, Y., KURATA, H., KAWASE, T., KUBO, T., Chem. Asian J., 3, 2008, p. 20242032

2. RONCALI, J., THOBIE-GAUTIER, C., BRISSET, H., FAVART, J.F., GUY, A., J. Electroanal. Chem., 381, 1995, p. 257-260.

3. ROQUET, S., DE BETTIGNIES, R., LERICHE, P., CRAVINO, A., RONCALI, J., J. Mater. Chem., 16, 2006, p. 3040-3045.

4. KLEYMYUK, E.A., TROSHIN, P.A., KHAKINA, E.A., LUPONOSOV, Y.N., MOSKVIN, Y.L., PEREGUDOVA, S.M., BABENKO, S.D., MEYERFRIEDRICHSENE, T., PONOMARENKO, S.A., Energy Environ. Sci., 3, 2010, p. 1941-1948.

5. LANGE, U., ROZNYATOUSKAYA, N.V., MIRSKY, V.M., Anal. Chim. Acta. 2008, 614, 1-26.

6. DIMA, S.-O., SARBU, A., TANASE, D., BRADU, C., ANTOHE, N., RADU, A.-L., NICOLESCU, T.-V., LUNGU, A., Mat.Plast., 46, no.4, 2009, p. 372378.

7. DIMA, S.-O., SARBU, A., TANASE, D., PURCAR, V., NICOLAE, C.A., Ma.Plast., 49, no.2, 2012, p. 106-113.

8. FLOREA, A.-M., IORDACHE, T.-V., ZAHARIA, A.-M., GEORGESCU, B., VOICU, A.-E., TSYNTSARSKI, B., HUBCA, G., SARBU, A., Mat.Plast., 54, no.3, 2017, p. 495-501.

9. MALITESTA, C., MAZZOTTA, E., PICCA, R.A., POMA, A., CHIANELLA, I., PILETSKY, S.A., Anal. Bioanal. Chem., 402, 2011, p. 1827-1846.

10. PERNITES, R., PONNAPATI, R., FELIPE, M.J., ADVINCULA, R., Biosens. Bioelectron., 26, 2011, p. 2766-2771.

11. SHARMA, P.S., WOJ NAROWICZ, A., SOSNOW SKA, M., BENINCORI, T., NOWORYTA, K., D'SOUZA, F., KUTNER, W., Biosens. Bioelectron., 77, 2016, p. 565-572.

12. DYSHLYUK, A.V., VITRIK, O.B., KULCHIN, Y.N., MITSAI, E.V., CHEREPAKHIN, A.B., BRANGER, C., BRISSET, H., IORDACHE, T.V., SARBU, A., J. Light. Tech., 35, 2017, p. 5425-5431.

13. NAKAYAMA, J., LIN, J.-S., Tet. Lett., 38, 1997, p. 6043-6046. 14. KARIPIDES, A., REED, A.T., THOMAS, R.H.P., Acta Cryst., B30, 1974, p. 1372-1374.

15. HAN, B.-H., CHOI, M.-G., Acta Cryst., C56, 2000, p. 1001-1003. 16.CHALONER, P.A., GUNATUNGA, S. R., HITCHCOKC, P. B., Acta Cryst., C50, 1994, p. 1941-1942.

17.VAN BOLHUIS, F., WYNBERG, H., HAVINGA, E.E., MEIJER, E.W., STARING, E.G.J., Synthetic Metals, 30, 1989, p. 381-389.

Manuscript received: 23.07 .2018 